\title{
DUDUK SAMA RENDAH, BERDIRI SAMA TINGGI Nilai-Nilai Budaya Nelayan \& Petambak di Sambas, Kalimantan Barat
}

\author{
Deliana R. Pridaningsih
}

\author{
Dinas Kelautan dan Perikanan Kabupaten Sambas \\ Jl. Pembangunan Sambas, Kalimantan Barat 79162
}

\begin{abstract}
Until now, the traditional fishermen and fish farmers of Sambas still uphold traditional values as implemented as hereditary greet, such as drink coffee together and Saprahan meal which are small things for people of other communities. For these fishermen and fish farmers these daily activities mean a lot to tighten the brotherhood. In the midst of their life pressure, they kept alive these simple cultural values.

Key words: traditional values, fishermen, fish farmers, brotherhood, Sambas, West Kalimantan.

\section{Pendahuluan}

Apa yang ada di pikiran orang apabila mendengar istilah-istilah "nelayan" dan "petambak"? Mungkin yang terlintas di pikiran sebagian orang adalah tentang kerasnya kehidupan mereka, bahwa mereka kurang memiliki tata krama dan sopan santun, bahwa mereka cenderung arogan. Tapi, apakah kita pernah mencoba untuk memahami dan menyelami kehidupan mereka? Mungkin jawabannya "tidak," karena sikap sebagian anggota masyarakat cenderung memandang orang-orang lain beserta mata pencaharian dan karakteristik yang mengikutinya menurut kacamatanya sendiri.

Pada kesempatan ini, penulis mencoba menggambarkan tentang bagaimana kehidupan sosial-budaya nelayan dan petambak tradisional di Kabupaten Sambas yang umumnya adalah suku Melayu Sambas, khususnya di bagian daerah Sebangkau. Untuk mulai membahas judul dengan kalimat pendek namun bermakna cukup luas ini penulis memulai dengan pengertian tentang budaya atau kebudayaan, masyarakat, dan nelayan. Menurut penulis, budaya merupakan sesuatu yang telah dimiliki oleh setiap individu dan
\end{abstract}


tersimpan jauh di dalam pikiran setiap individu tersebut, baik disadari ataupun tidak. Sejak lahir, setiap individu memiliki budaya, mulai dari cara mandi, cara berpakaian yang sopan, cara makan yang baik, dan sebagainya. Semuanya tersirat, walaupun tak selalu tersurat, mulai dari hal-hal yang terkecil.

Secara konseptual kebudayaan dapat dipahami sebagai perwujudan dari kegiatan manusia. Wujud pertama kebudayaan berupa suatu kompleksitas dari ide-ide, gagasan, nilai-nilai, norma-norma, dan peraturan. Kebudayaan dalam wujud ini, sifatnya abstrak tak dapat diraba atau difoto, dan tempat penyimpanan ide-ide ini ada di balik kepala atau di dalam pikiran warga masyarakat di mana kebudayaan yang bersangkutan itu hidup. Kalau gagasan tadi telah dialihkan dalam bentuk tulisan atau coretan atau gambar, maka tempatnya ada dalam karangan, buku-buku, disk, arsip, koleksi mikrofilm, lukisan berbingkai dan sebagainya. Semua ide yang berupa gagasan, nilai-nilai, norma dan peraturan merupakan hasil karya para warga masyarakat yang bersangkutan. Gagasangagasan tadi menjadi suatu sistem, dan memberi jiwa kepada masyarakat yang bersangkutan, sehingga disebut sistem budaya (Koentjaraningrat, 1984: 187). Sistem budaya ini merupakan tingkat yang paling tinggi dan abstrak karena merupakan konsepkonsep yang hidup dalam alam pikiran sebagian besar dari warga masyarakat. Sistem nilai budaya lantas menjadi pedoman yang memberi arah dan orientasi kehidupan para warga masyarakat tadi. Sebagai pedoman, nilai-nilai budaya berada di dalam daerah emosional dari alam jiwa para individu pendukung kebudayaan yang bersangkutan.

Kebudayaan yang dimiliki oleh manusia juga dimiliki dengan cara belajar. Dia tidak semata-mata diturunkan secara biologis atau pewarisan melalui unsur genetis. Hal ini perlu ditegaskan untuk membedakan perilaku manusia yang digerakkan oleh kebudayaan dengan perilaku mahluk lain yang tingkah lakunya digerakkan oleh insting (Siregar, 2002). Pada umumnya kebudayaan itu dikatakan bersifat adaptif, karena kebudayaan melengkapi manusia dengan cara-cara penyesuaian diri pada kebutuhankebutuhan fisiologis dari badan mereka, dan penyesuaian pada lingkungan yang bersifat fisik geografis maupun pada lingkungan sosialnya. Banyak cara yang wajar dalam hubungan tertentu pada suatu kelompok masyarakat yang memberi kesan janggal pada kelompok masyarakat yang lain, tetapi jika dipandang dari hubungan masyarakat tersebut dengan lingkungannya, baru hubungan tersebut bisa dipahami. Misalnya, orang akan 
bertanya, kenapa ada pantangan-pantangan menangkap ikan pada bulan-bulan tertentu pada masyarakat pesisir. Bagi orang di luar kebudayaan tersebut, pantangan tersebut susah dimengerti, tetapi bagi masyarakat pendukung kebudayaan yang melakukan pantangan-pantangan seperti itu, hal tersebut mungkin suatu cara menyesuaikan diri pada lingkungan fisik tempat mereka berada (Siregar, 2002).

\section{Kabupaten Sambas}

\section{1. Letak Geografis}

Dengan luas $6.395,70 \mathrm{Km}^{2}$ atau sekitar 4,35 persen dari luas Provinsi Kalimantan Barat, Kabupaten Sambas terletak di ujung utara Propinsi Kalimantan Barat, berbatasan langsung dengan Sarawak, Malaysia. Kabupaten Sambas mencakup 19 kecamatan, 183 desa dan 1 UPT, yang secara administratif berbatasan dengan beberapa wilayah sebagai berikut: (1) di sebelah utara dengan Serawak, Malaysia Timur dan Laut Natuna; (2) di sebelah barat dengan Laut Natuna; (3) di sebelah timur dengan Kabupaten Bengkayang dan Negara Bagian Serawak; dan (4) di sebelah selatan dengan Kabupaten Bengkayang dan Kota Singkawang.

Di antara ke-19 kecamatan tersebut terdapat lima kecamatan pesisir, yaitu Kecamatan Selakau, Kecamatan Pemangkat, Kecamatan Jawai, Kecamatan Teluk Keramat, dan Kecamatan Paloh. Kelima Kecamatan tersebut membentang dari utara yaitu Kecamatan Paloh ke selatan di Kecamatan Selakau dalam garis pantai sepanjang $198,76 \mathrm{~km}$.

\section{2. Kondisi Fisik Kecamatan Pemangkat}

Kecamatan Pemangkat terdiri atas 5 (lima) desa yang berada pada posisi $1^{0} 05$ '01" $1^{0} 12$ '14" LU dan $108^{0} 54^{\prime} 01^{\prime \prime}$ - 10904'49” BT. Luas wilayah Kecamatan Pemangkat adalah $111,00 \mathrm{~km}^{2}$, atau setara dengan 1,74\% dari luas Kabupaten Sambas. Sampai awal tahun 2008 penduduk Kecamatan Pemangkat adalah 46.182 jiwa yang terdiri atas 23.641

jiwa penduduk laki-laki, dan 22.341 penduduk wanita dengan sex ratio 102,18 yang berarti terdapat 102 laki-laki di antara 100 penduduk perempuan.

Panjang garis pantai Kecamatan Pemangkat adalah 20,49 km dengan perairan laut $151,162 \mathrm{~km}^{2}$. Nelayan di Kabupaten Sambas pada umumnya tidak memiliki aturan adat dalam upaya penangkapan ikan. Tidak ditemukan kelembagaan adat dalam penangkapan 
ikan seperti Sasi di Maluku atau Panglima Laot di Aceh. Nelayan di wilayah ini dapat secara bebas melakukan penangkapan ikan sesuai dengan kemampuannya sepanjang tahun. Faktor yang membatasi penangkapan ikan hanya pengaruh musim, yang berhubungan dengab gelombang laut dan ketersediaan ikan. Kelompok nelayan merupakan kelembagaan yang ada saat ini, dengan struktur kepengurusan ketua, sekretaris, dan bendahara. Kelompok nelayan ini belum tampak dalam hal pengaturan penangkapan atau dalam berperan menjaga kelestarian sumberdaya kelautan. Peran kelompok nelayan adalah menyuarakan aspirasi nelayan terhadap pihak luar, misalnya mewakili nelayan merespon program-program yang direncanakan dan dilaksanakan oleh pemerintah.

Interaksi sosial dan ekonomi dilakukan nelayan dengan pedagang sebagai sarana input dan umumnya mereka sudah mendapatkan pinjaman-pinjaman modal untuk kegiatan melautnya. Nelayan yang sudah mendapat pinjaman modal akan menjual ikan hasil tangkapannya kepada pedagang sarana input yang sekaligus juga penampung hasil laut sebagai balas jasa, sehingga ada keterikatan antara nelayan dan pemodal; hal ini umumnya disebabkan karena lemahnya permodalan di kalangan nelayan. Nelayan seperti ini umumnya tidak memiliki kapal motor atau sering disebut nelayan buruh, sedangkan nelayan yang memiliki kapal motor disebut nelayan pemilik, yaitu mereka yang lebih bebas dalam melakukan hubungan dengan para pelaku ekonomi lainnya, yang didasarkan pada keuntungan dengan posisi tawar yang lebih baik.

\section{Kegiatan dan Pandangan Nelayan dan Petambak Tradisional}

Karakteristik nelayan, menurut Satria (2002), berbeda dari petani. Nelayan menghadapi sumberdaya yang hingga kini masih bersifat open access. Karakteristik sumberdaya seperti ini menyebabkan nelayan harus berpindah-pindah untuk memperoleh hasil maksimal. Dengan demikian, elemen risikonya menjadi sangat tinggi. Kondisi sumberdaya yang berisiko menyebabkan masyarakat nelayan memiliki karakter keras, tegas, dan terbuka. Pagi hari, tepatnya setelah adzan subuh, para nelayan togo dan petambak sudah mulai beraktivitas; togo merupakan alat tangkap pasif atau perangkap (DKP, 2006). Nelayan togo sudah mulai mempersiapkan togo yang akan dipasang pada tiang-tiang pancang yang sudah diatur dan dipasang oleh nelayan yang bersangkutan di pesisir pantai. Togo dipasang pada saat air surut dan hasilnya dipanen setelah pasang 
tertinggi pada hari yang sama. Waktu yang dibutuhkan untuk menyelesaikan pekerjaan mereka lebih kurang 5 jam per hari. Hasil dari togo berupa ikan-ikan yang hidup di pesisir serta udang rebon yang berukuran sangat kecil. Ikan segar yang berukuran agak besar akan langsung dijual ke pengumpul, sedangkan ikan-ikan yang berukuran kecil diolah lebih lanjut untuk dijadikan ikan asin. Khusus udang rebon dibawa pulang ke rumah mereka untuk diolah lebih lanjut oleh para istri nelayan tradisional menjadi terasi dan peda cencalo.

Para istri nelayan umumnya mendapat tugas untuk mengolah hasil tangkapan menjadi produk olahan tradisional. Untuk mengolah terasi, mereka menggunakan alat tradisional berupa alu dan lesung. Untuk menghasilkan terasi sebanyak $40 \mathrm{~kg}$, mereka membutuhkan waktu lebih kurang 5 (lima) hari, dan lama waktu per hari yang dibutuhkan untuk menghasilkan terasi tersebut sekitar 4 (empat) jam tanpa istirahat. Jadi, setelah dikalkulasikan, ternyata beban pekerjaan laki-laki dan perempuan adalah sama. Turut mengikuti dan merasakan seluruh aktivitas mereka membuat penulis semakin mengerti, betapa besar pengorbanan yang dibutuhkan demi mendapatkan sesuap nasi. Apakah suami mereka akan pulang dengan selamat dan membawa hasil? apakah istri mereka dapat membantu suami sekaligus mengurus anak? apakah ke depan nantinya kehidupan mereka akan lebih baik? itulah pertanyaan-pertanyaan yang secara tersirat bisa penulis pahami walau tidak pernah diucapkan.

Para istri dan wanita cenderung diam dan menetap di rumah. Mereka sangat jarang ke luar "ke kota" karena menurut mereka, terutama para laki-laki, di sana "wanita tidak perlu mengetahui urusan mereka, tugas mereka adalah mengurus rumah, suami, anak, dan semua urusan dapur." Mungkin menurut sebagian besar orang yang berpijak di atas paradigma modern menganggap persepsi ini keliru, namun bagi para nelayan dan petambak tradisional ini adalah benar, karena mereka menganggap wanita memiliki kedudukan yang jauh lebih rendah dari laki-laki; pada saat penulis melakukan penelitian, mereka hanya memandang penulis sebelah mata. Bagi mereka, "dipimpin" oleh seorang wanita seperti sebuah "penghinaan." Mereka seolah-olah tidak menyadari bahwa mereka juga dilahirkan oleh seorang wanita. Namun hal itu tidak membuat penulis menjadi gentar dan mudur beberapa langkah, justru penulis ingin menggali lebih jauh bagaimana pendapat mereka yang sebenarnya. Penulis mengikuti seluruh aktivitas perikanan di sana, 
seperti mengikuti rapat kelompok, ikut melaut bersama nelayan yang seluruhnya adalah laki-laki, ikut kegiatan pertambakan dan membantu mereka dalam hal pengukuran kualitas air mulai pagi hari hingga malam hari, ikut kegiatan para wanita dan istri nelayan dalam hal pengolahan hasil perikanan. Walaupun awalnya penulis menjadi satu-satunya wanita muda di antara laki-laki yang lebih tua dan sangat aneh bagi mereka, ternyata setelah penulis membaur bersama mereka dan secara tidak langsung, sedikit memberikan pengertian kepada mereka tentang posisi dan kemampuan wanita pada masa kini. Akhirnya mereka mulai memahami dan bisa menerima penulis.

Pada pagi hari yang sama, setiap harinya petambak tradisional juga beraktivitas di tambak mereka. Semua petambak di Sebangkau mengusahakan tambak secara tradisional (ekstensif) dengan komoditas udang windu dan ikan bandeng secara bersamaan (polikultur). Pilihan budidaya secara polikultur ini di latarbelakangi terutama oleh kemampuan ekonomi petambak. Alasan lainnya adalah karena mereka kurang menguasai teknologi budidaya udang windu, sehingga kemungkinan gagal cukup besar apabila menerapkan pola monokultur udang windu. Walaupun kenyataannya mereka mengharapkan hasil terutama dari udang windu karena tidak susah dalam pemasarannya dan mempunyai nilai ekonomi tinggi.

Dalam hal melaut dan bertambak, mereka masih percaya pada kata "takabur." Setiap melaut atau bertambak, tidak boleh terucap dari mulut mereka bahwa mereka akan dapat hasil yang sangat banyak serta untung besar karena begitu terucap maka yang terjadi justru sebalikya. Mengenai kebenarannya, penulis juga kurang paham. Namun sebetulnya yang terjadi adalah, saat mereka sangat yakin akan dapat hasil yang banyak, mereka menjadi sedikit lengah dalam melakukan aktivitasnya sehingga hasil yang diperoleh menjadi kurang maksimal.

\section{Pendidikan Nelayan dan Petambak}

Sebagian besar nelayan dan petambak di Sebangkau berpendidikan formal hanya sampai dengan tingkat Sekolah Dasar (61,9 persen). Sebagian besar (70 \%) nelayan dan petambak hanya mempunyai tingkat pendidikan sampai dengan Sekolah Dasar, $10 \%$ tamat SLTP dan $20 \%$ tamat SLTA. Tingkat pendidikan yang rendah ini disebabkan karena sebagian besar petambak berumur 41-59 tahun, di mana pada masa usia sekolah sarana dan prasarana pendidikan di Sebangkau terbatas, di samping keadaan ekonomi 
keluarga petambak yang kurang mendukung untuk mendapat pendidikan yang lebih tinggi.

Pelatihan mengenai pertambakan sebagai pendidikan non-formal bagi seluruh petambak dilakukan beberapa kali oleh Dinas Kelautan dan Perikanan Kalimantan Barat. Pelatihan tersebut nampaknya kurang efektif dalam meningkatkan pengetahuan budidaya tambak bagi petambak, karena pada kenyataannya petambak masih belum menguasai budidaya tambak dengan baik. Petambak lebih banyak belajar melalui pengalaman tentang budidaya tambak, namun hal ini kurang efektif karena petambak tersebut tidak memiliki dasar pengetahuan budidaya perikanan, begitu juga dengan para nelayan.

\section{Kehidupan Sosial Nelayan dan Petambak}

Di tengah kerasnya kehidupan para nelayan dan petambak tradisional yang selalu berusaha untuk memenuhi kebutuhan mereka dari segi finansial dengan segenap tenaga dan semangat yang mereka miliki, jarang sekali terdengar keluhan mereka. Mereka selalu mensyukuri apa yang mereka miliki dan mengikhlaskan apa yang tidak bisa mereka dapatkan. Wajah yang seram dan karakter yang keras sebetulnya bukanlah gambaran

yang sebenarnya dari diri mereka. Namun, kebaikan mereka cenderung hampir tidak terlihat, mungkin hal ini disebabkan oleh tutur kata mereka yang cenderung tidak tertata dan sedikit kasar. Walaupun mereka sibuk untuk mencari nafkah, mereka tidak pernah lupa untuk melaksanakan kegiatan yang merupakan suatu tradisi di Desa itu, suatu pesta yang lebih akrab dengan kata "karamaian" yang merupakan ajang bagi mereka untuk berkumpul bersama. Beberapa kebiasaan yang menjadi tradisi yang tetap dilaksanakan secara turun-temurun hingga saat ini seperti bertegur sapa, minum kopi bersama, dan Saprahan yang merupakan hal-hal kecil yang mungkin bagi orang-orang yang cenderung individualistis adalah sesuatu yang membosankan, namun bagi mereka sangat berarti untuk mempererat tali silaturahmi. Secara singkat tradisi-tradisi tersebut dapat disampaikan sebagai berikut.

\section{1. Tegur Sapa}

Tegur sapa bukanlah suatu kewajiban bagi masyarakat di seluruh penjuru dunia, terutama Kabupaten Sambas, khususnya di Sebangkau. Namun, lebih tepatnya, tegur sapa merupakan suatu cara dan tradisi yang dilakukan turun-temurun untuk menyatakan bahwa mereka peduli terhadap sesama, bahwa mereka ingin mengetahui bagaimana 
keadaan dan kondisi sesamanya, sekaligus untuk menyatakan bahwa mereka adalah mahluk sosial yang saling membutuhkan antara yang satu dengan lainnya. Apabila ada salah satu dari warga masyarakat, baik yang masih memiliki hubungan keluarga maupun tidak ada sama sekali, maka tanpa ada unsur paksaan dan tanpa pamrih mereka akan langsung mengunjungi dan memberikan bantuan semampunya.

Sapaan-sapaan "Mau kemane," “dari mane," “agek ngape kitak," "si anok tang sean i...." merupakan wujud kepedulian mereka terhadap sesama. Namun, terkadang orang-orang yang umumnya berasal dari kota cenderung keliru mengartikannya sehingga menganggap sapaan mereka sebagai wujud rasa ingin tahu yang terlalu besar dan dianggap mengganggu privasi. Padahal, sebenarnya, menyapa atau membalas sapaan dengan ikhlas, atau mungkin hanya sekedar mengukir senyum bukanlah sesuatu yang sulit untuk dilakukan sepanjang kita melakukannya dengan ikhlas.

\section{2. Minum Kopi Bersama}

Malam hari, saat semua orang telah selesai beraktivitas merupakan saat bagi mereka untuk berbagi. Secangkir kopi merupakan minuman khas seluruh masyarakat kabupaten Sambas, khususnya di Sebangkau sebagai pengantar komunikasi. Setiap ada tamu yang datang ke rumah mereka, baik yang sudah dikenal maupun tamu asing yang belum pernah mereka kenali, maka secangkir kopi menjadi hidangan pembuka yang "tidak boleh" ditolak. Menurut masyarakat Kabupaten Sambas, apabila kita disuguhi dengan secangkir kopi maka wajib untuk diminum dan dihabiskan karena apabila kita tidak meminumnya, maka sesuatu yang buruk pasti akan terjadi, baik dalam waktu dekat maupun yang akan datang. Mereka akan sangat tersinggung apabila kita tidak meminum secangkir kopi yang mereka hidangkan. Bagi mereka itu adalah suatu penghinaan. Namun, apabila kita meminum kopi tersebut, maka mereka akan sangat senang dan mulai mau membuka diri dengan sedikit bercerita dan bercanda seolah-olah mereka telah lama mengenal kita. Jadi pada prinsipnya, mereka akan menerima kita apa adanya sebagaimana kita menerima mereka.

\section{3. Saprahan}

Saprahan merupakan suatu tradisi makan bersama dalam suatu acara, baik pesta pernikahan maupun pesta lainnya yang dilakukan oleh masyarakat Kabupaten Sambas, khususnya oleh para nelayan dan petambak di Kabupaten Sambas. Hidangan sebanyak 
"satu saprah" terdiri enam orang yang duduk bersila yang membentuk sebuah lingkaran kecil dan makan bersama dengan menggunakan tangan sebagai alat makan, dengan laukpauk yang umumnya terdiri dari ayam sebanyak seperempat bagian yang sudah dimasak (semur, opor atau masakan berkuah lainnya), telur acar sebanyak tiga butir, yaitu telur rebus yang dipotong menjadi dua bagian sehingga akhirnya berjumlah enam kemudian diberi kuah acar, ditambah sambal goreng berkuah santan yang berisi kentang yang dipotong kecil-kecil dengan sedikit petai dan potongan daging berukuran kecil (setengah $\mathrm{cm})$.

Dalam satu tempat atau ruangan, baik terbuka maupun tertutup terdapat beberapa saprah atau beberapa lingkaran kecil. Makan Saprahan yang sudah menjadi adat budaya bertujuan untuk meningkatkan silaturahmi dan ukhuwah, hubungan baik antar manusia, dengan semangat gotong-royong yang sangat kental tanpa membedakan latar belakang seseorang apakah dia itu unsur pejabat, tokoh maupun orang yang dituakan.

Tradisi makan Saprahan ini memiliki makna "duduk sama rendah berdiri sama tinggi” yang terkesan sangat kental dengan rasa kebersamaan dan kesetiakawanan sosial, duduk bersila sambil menikmati aneka rasa masakan selera melayu. Tidak ada perbedaan di antara mereka, semuanya terhapus oleh kebersamaan yang tercipta. Duduk melantai, sambil menikmati hidangan, bercerita dan bercanda merupakan ciri khas dari Saprahan. Apapun status sosial mereka, baik yang miskin maupun yang kaya, baik tua maupun muda, baik besar maupun kecil, baik pejabat maupun orang biasa saja, sepanjang mereka masih mau duduk bersama di atas lantai yang beralaskan "tikar daun," sepanjang mereka masih mau berada di bawah naungan langit yang sama, sepanjang mereka masih menghirup udara yang sama, maka tidak ada perbedaan dan pembatas di antara mereka karena pada prinsipnya kita adalah sama. Semua yang kita miliki di dunia ini hanyalah titipan yang Maha Kuasa. Semuanya hanyalah sementara dan tidak ada satupun yang abadi. Itulah makna yang tersurat dari duduk sama rendah berdiri sama tinggi.

\section{Kesimpulan}

Beberapa bulan hidup dan beraktivitas bersama mereka serta beberapa tahun mendampingi kegiatan mereka membuat penulis cukup memahami karakter mereka. Wajah yang seram dan karakter yang keras sebetulnya bukanlah gambaran yang sebenarnya dari diri mereka. Namun, kebaikan mereka cenderung hampir tidak terlihat, 
mungkin, hal ini disebabkan oleh tutur kata mereka yang cenderung tidak tertata dan sedikit kasar sesuai dengan karakteristik nelayan dan petambak yang keras dan banyak tantangan, terutama tantangan alam dan hasil alam yang tidak pasti.

Secangkir kopi merupakan minuman khas masyarakat Kabupaten Sambas, khususnya di Sebangkau sebagai hidangan pembuka pengantar komunikasi. Intisari yang terkandung dari makna secangkir kopi adalah bahwa pada prinsipnya mereka akan menerima kita apa adanya sebagaimana kita menerima mereka. Pahitnya rasa kopi ibarat gambaran dari hidup ini, walaupun pahit mereka tetap akan menelannya karena mereka yakin bahwa sepahit apapun kehidupan suatu saat pasti akan ada setitik rasa manis.

Apapun status sosial mereka, baik yang miskin maupun yang kaya, baik tua maupun muda, baik besar maupun kecil, baik pejabat maupun yang biasa saja, sepanjang mereka masih mau duduk bersama di atas lantai yang beralaskan "tikar daun," sepanjang mereka masih mau berada di bawah naungan langit yang sama, sepanjang mereka masih menghirup udara yang sama, maka tidak ada perbedaan dan pembatas diantara mereka karena pada prinsipnya kita adalah sama. Semua yang kita miliki di dunia ini hanyalah titipan yang Maha Kuasa. Semuanya hanyalah sementara dan tidak ada satupun yang abadi. Itulah makna yang tersurat dari duduk sama rendah berdiri sama tinggi. Seandainya semua orang yang hidup di muka bumi ini memahami arti sesungguhnya dari kehidupan, maka tidak ada kesombongan yang bisa dibanggakan. Itulah pelajaran dari duduk sama rendah berdiri sama tinggi yang kita peroleh dari masyarakat nelayan dan petambak Sambas.

\section{Daftar Pustaka}

BKI (Badan Kerjasama dan Industri). 2008. Laporan Akhir Penelitian dan Pengkajian Potensi Sumberdaya Kelautan. Sambas: Badan Kerjasama dan Industri Sambas.

Dirjen Perikanan Tangkap. 2006. Klasifikasi Alat Penangkapan Ikan. Jakarta: Departemen Kelautan dan Perikanan.

Satria, A. 2002. Pengantar Sosiologi Masyarakat Pesisir. Jakarta: P.T. Pustaka Cidesindo. 
Siregar, L. 2002. "Antropologi dan Konsep Kebudayaan." Jurnal Antropologi Рариа. Vol. 1, No. 1.

Thohir, Mudjahirin. 2007. Memahami Kebudayaan: Teori Metodologi dan Aplikasi. Semarang: Fasindo Press. 


\section{LAMPIRAN}

\section{FOTO-FOTO AKTIVITAS PETAMBAK DAN NELAYAN TRADISIONAL DI KABUPATEN SAMBAS}

\section{Aktivitas Petambak Tradisional}
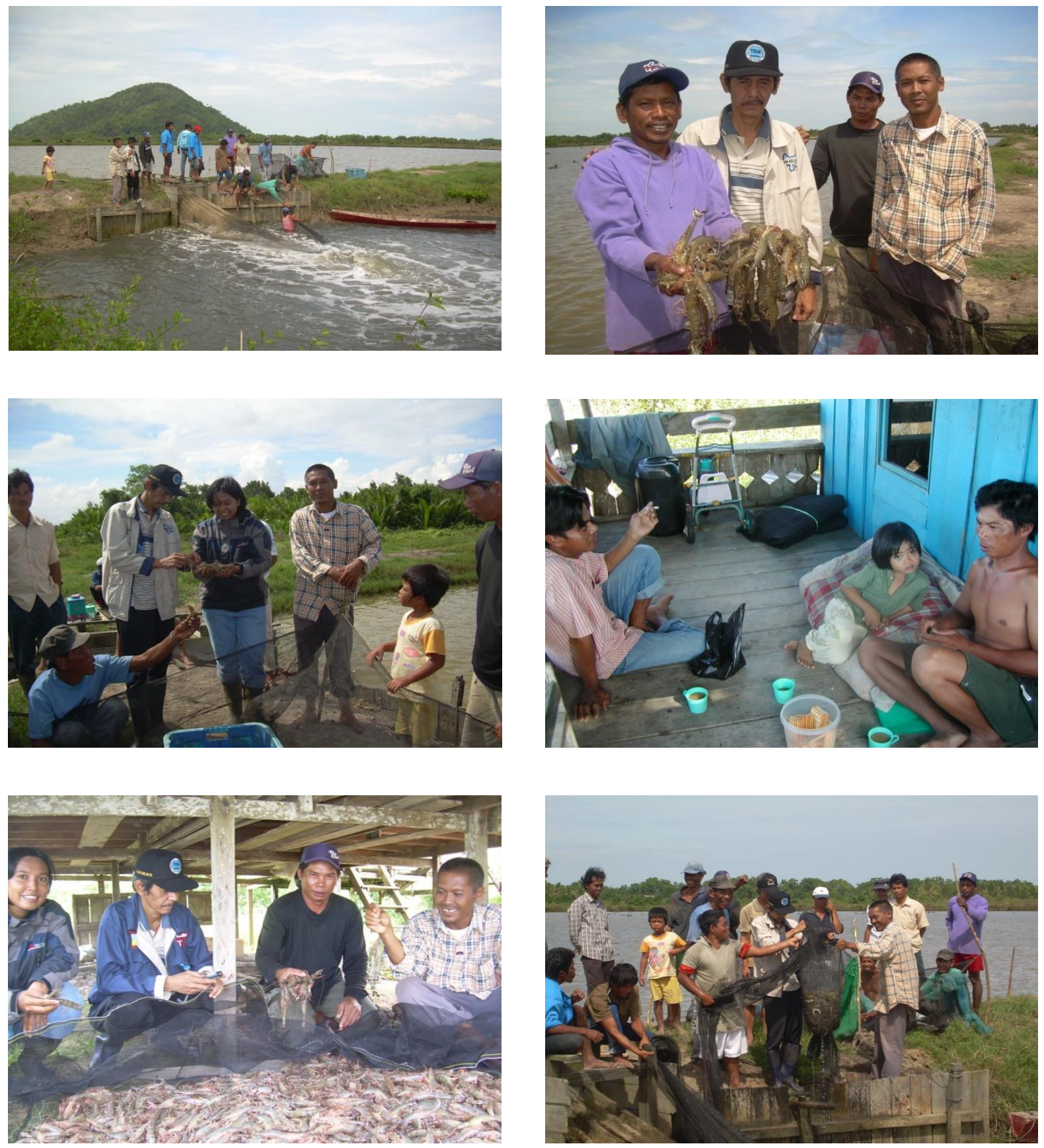


\section{Aktivitas Nelayan Tradisional}
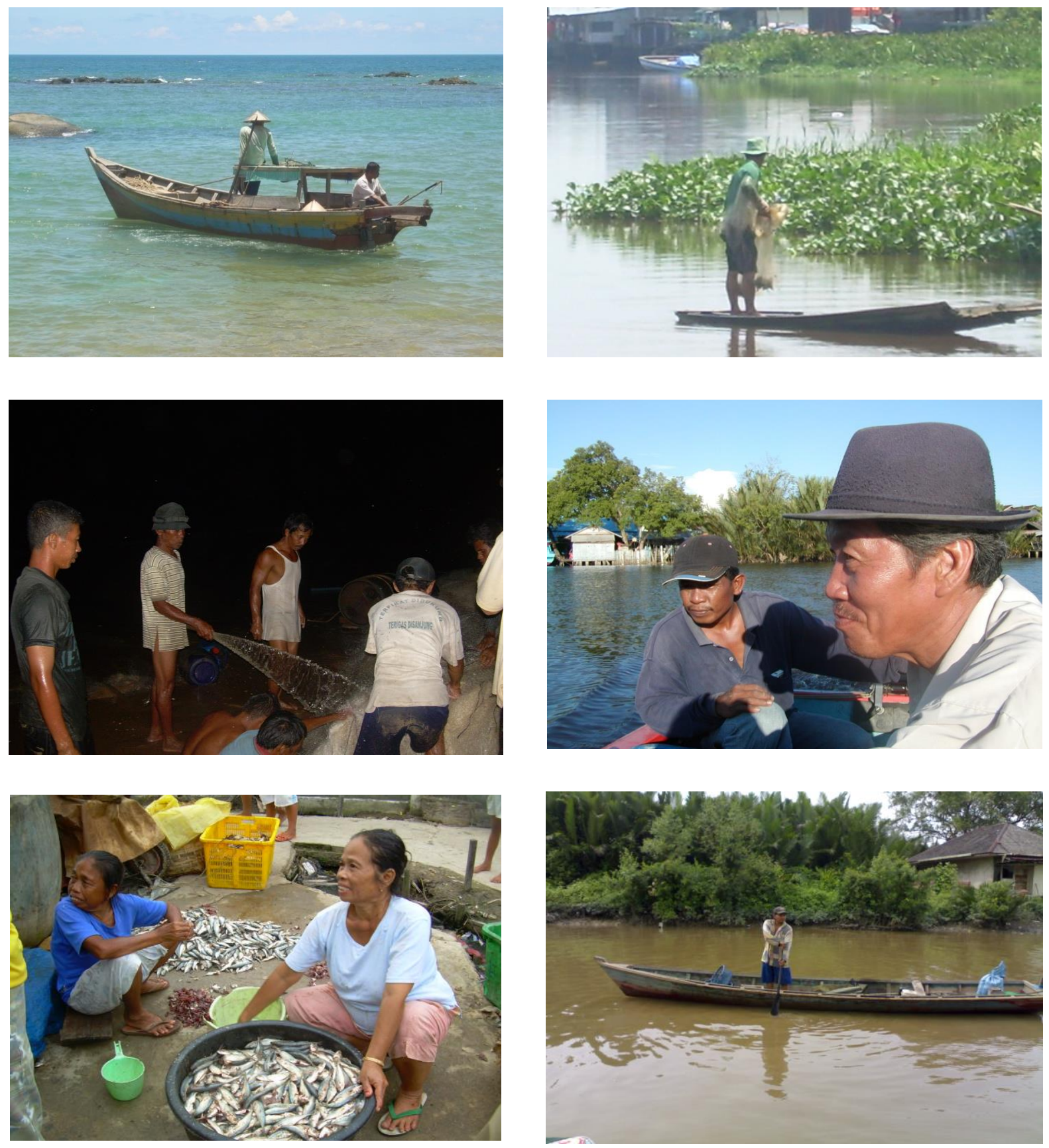

Keterangan: Foto-foto adalah dokumen pribadi penulis yang diambil pada tahun-tahun 2005-2008. 